\title{
Attribution, Responsibility and Jurisdiction in International Human Rights Law
}

Fecha de recepción: 15 de diciembre de 2015

Fecha de aceptación: 13 de mayo de 2016

Doi: $10.12804 /$ revistas.urosario.edu.co/acdi/a.5292

\section{Lucius Caflisch* $^{*}$}

Abstract: This paper deals with the attribution of responsibility to States Parties for violations of selected multilateral human rights treaties outside their territory, and the jurisdiction of the treaty organs over such violations. Jurisdiction over human rights violations may result from territorial sovereignty, but also from quasi-territorial domination (occupation and similar situations, jurisdiction over marine spaces) or from the exercise of personal jurisdiction such as activities by consular, diplomatic, or intelligence agents in foreign countries, acts by or on vessels on the high seas, or on air or space craft. For each of the treaty systems examined (African Charter of Human and Peoples' Rights, American Convention on Human Rights, United Nations Covenant on Civil and Political Rights, European Convention on Human Rights), this contribution describes the system's general features, its provisions on jurisdiction, and most importantly, the practices it generates. This allows for a number of conclusions: that all the mechanisms examined contain some compulsory elements, that all of them except the African system contain pertinent rules, and that

* Professor emeritus, Graduate Institute of International and Development Studies, Geneva; Judge of the European Court of Human Rights, Strasbourg (1998-2006); member of the International Law Commission of the United Nations (2006-2016). E-mail: caflisch.lda@bluewin.ch

Para citar este artículo: Caflisch, L., "Attribution, Responsibility and Jurisdiction in International Human Rights Law”, Anuario Colombiano de Derecho Internacional (ACDI), 2017, 10, pp. 161-203. Doi: 10.12804/revistas. urosario.edu.co/acdi/a.5292 
all of these mechanisms apply the classical rules of international law on the exercise of quasi-territorial and personal jurisdiction. States are responsible for the breaches of human rights standards committed by their agents and organs in the exercise of such jurisdiction, and treaty organs are entitled to deal with such breaches.

Key words: African Charter on Human and Peoples' Rights, American Convention on Human Rights, control over territory, European Convention on Human Rights, quasi-territorial jurisdiction, State responsibility for human rights violations, sanctions for human rights violations, United Nations.

\section{Atribución responsabilidad y jurisdicción en el Derecho Internacional de los Derechos Humanos}

Resumen: este artículo se ocupa de la atribución de la responsabilidad a los Estados Parte por violaciones de ciertos tratados multilaterales de derechos humanos fuera de su territorio y la jurisdicción de los tribunales u órganos de tratado sobre dichas violaciones. La jurisdicción sobre la violación de los derechos humanos es resultado de la soberanía territorial pero también, incluso, de la dominación cuasi territorial (ocupación territorial y situaciones similares, la jurisdicción sobre territorio marítimo) o del ejercicio de jurisdicción personal por parte de las autoridades competentes, tales como actividades consulares, diplomáticas o de inteligencia en países extranjeros, actos en o por embarcaciones marítimas en altamar o en naves de aire o espaciales. Para cada uno de los sistemas de tratados revisados, (Carta Africana sobre los Derechos Humanos y de los Pueblos, Convención Americana de Derechos Humanos, Pacto Internacional de Derechos Civiles y Políticos, Convención Europea sobre Derechos Humanos) este documento describe las características generales del sistema, sus disposiciones sobre jurisdicción y, lo más importante, la prácticas derivada de su aplicación. Este documento propone las siguientes conclusiones: todos los mecanismos revisados contienen algún elemento preceptivo/obligatorio; todos ellos, excepto el sistema Africano, contienen reglas pertinentes y asimismo todos aplican las reglas clásicas del derecho internacional en el ejercicio de la competencia cuasi territorial y personal. Estos Estados son responsables por las violaciones de derechos humanos cometidas por sus agentes y órganos en el ejercicio de su soberanía y los órganos del tratado pueden conocer de estos abusos. 
Palabras clave: carta Africana sobre los Derechos Humanos y de los Pueblos ACNuR, Convención Americana sobre Derechos Humanos, control sobre el territorio, Convención Europea de Derechos Humanos, jurisdicción cuasiterritorial, responsabilidad del Estado por violación del DIDH, sanciones por violación de los derechos humanos, Naciones Unidas.

\section{Adjudicação, responsabilidade e jurisdição no Direito} Internacional dos Direitos Humanos

Resumo: Este artigo ocupa-se da atribuição da responsabilidade de Estados membro por violações de tratados multilaterais de direitos humanos fora de seu território e a jurisdição dos organismos de controle sobre ditas violações. A jurisdição sobre a violação dos direitos humanos é resultado da soberania territorial, mas também, inclusive, da dominação quase territorial (ocupação territorial e situações similares, a jurisdição sobre território marítimo) ou do exercício das autoridades competentes, tais como atividades consulares, diplomáticas ou de inteligência em países estrangeiros, atos em ou por embarcações marítimas em alto-mar ou em navios de ar ou espaciais. Para cada um dos sistemas de tratados revisados (Carta Africana sobre os Direitos Humanos e dos Povos, Convenção Americana de Direitos Humanos, Pacto Internacional de Direitos Civis e Políticos, Convenção Europeia sobre Direitos Humanos) este documento descreve as características do sistema geral, suas disposições sobre a jurisdição e, o mais importante, as práticas que tem gerado. Este documento propõe as seguintes conclusões: todos os mecanismos revisados contém algum elemento preceptivo/obrigatório; todos eles, exceto o sistema Africano, contém regras pertinentes e assim mesmo todos aplicam as regras clássicas do direito internacional no exercício pelas violações de direitos humanos cometidas por seus agentes e organismos no exercício da sua soberania e os organismos de controle tem direito a tratar qualquer deste abusos.

Palavras-chave: Carta Africana sobre os Direitos Humanos e dos Povos ACNUR, Convenção Americana sobre Direitos Humanos, controle sobre o território, Convenção Europeia de Direitos Humanos, jurisdição quaseterritorial, responsabilidade do Estado por violação do DIDH, sanções por violação dos direitos humanos, Nações Unidas. 


\section{Attribution, Responsibility and Jurisdiction in International Human Rights Matters}

General international law distinguishes between jurisdiction ratione loci, ratione personae and ratione temporis. This study relates to jurisdiction ratione loci and ratione personae, and to organs, especially judicial organs, that ensure the international protection of human rights. The questions addressed are: When is a State Party to a treaty system responsible for the unlawful conduct of its organs; is this responsibility affected by the identity of the persons to whom this conduct is directed; and when do these organs have jurisdiction to deal with such matters? ${ }^{1}$ On the level of general international law, a State may act on its own territory as a sovereign (agir à titre de souverain) in the legislative, executive, and judicial fields, regardless of whether such conduct affects its nationals or aliens. This entails the State's duty to behave in accordance with the rules of international law. In principle, a failure to conform to international law when acting in relation to a foreign individual engages the State's international responsibility vis-à-vis that individual's national State and entitles the latter, if certain conditions are met, to undertake the individual's diplomatic protection. Such protection can also be exercised against States that have not acted à titre de souverain, but on the basis of overall short or long-term effective control, for instance in situations of military occupation. So much for the exercise of territorial or quasi-territorial jurisdiction and the international responsibility it entails.

There is also the exercise of personal jurisdiction, i.e., outside the State's territory or quasi-territory. A State may act on the territory of another State, or on the seas, in the air and in outer space, through its diplomatic or consular agents, and in so doing may breach rules of international law designed to protect individuals.

The rules on the international protection of buman rights are part and parcel of both conventional and customary international law, and some of these rules have the rank of jus cogens. ${ }^{2}$ A State that breaches such rules in the exercise of its territorial, quasi-territorial, or personal jurisdiction will be internationally responsible for its actions. The difference between these

\footnotetext{
1 See on this issue generally Da Costa, K. (2013). The Extraterritorial Application of Selected Human Rights Treaties. Leiden/Boston: Brill/Martinus Nijhoff Publishers.

2 On the issue of defining the rules of jus cogens, see for instance "Pratique suisse en matière de droit international public 2013," No. 2.3, Revue suisse de droit international et européen, Vol. 25, 2015, p. 68.
} 
situations and classical ones resulting from the exercise of diplomatic protection is that violations committed in the former will be considered internationally relevant even if the victim of the violation is a national of the State alleged to be responsible, and that it will no longer be the individual's national State which will act as his or her protector. Indeed, how could a State protect an individual against itself? It is the individual himself or herself who will directly bring a claim on the international level, acting as a subject of international law within the confines of international human rights law.

Accordingly, there is every reason to assume that what obtains in general international law regarding the exercise by States of territorial, quasi-territorial, and personal jurisdiction, applies equally to State responsibility and jurisdiction and to the jurisdiction of international human rights tribunals. It is hoped that this contribution will shed light on this issue. Some conclusions will be proposed after examining the law and practice of four major conventions providing protection mechanisms: the American Convention on Human Rights of 22 November 1969 (ACHR); the African Charter on Human and Peoples' Rights of 27 June 1981 (ACHPR); the International Covenant on Civil and Political Rights of 16 December 1966 (ICCPR) $;^{3}$ and the oldest of them, the European Convention on Human Rights of 4 November 1950 (ECHR). ${ }^{4}$

\section{Treaty Provisions on the Functioning of Systems to Protect Human Rights, International Responsibility and Jurisdiction}

\section{(a) The American Convention on Human Rights}

\section{(i) General Provisions}

The main institutions in the Americas for the international protection of human rights are the Inter-American Commission on Human Rights (IACHR) and the Inter-American Court of Human Rights (IACTHR).

Articles 44 to 50 of the ACHR deal with the Commission. Article 44 provides that persons, groups of persons, or non-governmental organisations (NGOs) legally recognised in one or several States Parties may lodge

3 These texts may be found, inter alia, in: Council of Europe (2007). Human Rights in International Law, $3^{\text {rd }}$ ed., Strasbourg: Council of Europe, pp. 309, 643, 579 and 33, respectively.

4 European Treaty Series No. 5. 
petitions with the IACHR without the need for any specific acquiescence or declaration of acceptance by the State Party concerned. The contrary is true for inter-State disputes: States Parties may however declare, pursuant to Article 45, that they recognise, for a determined or undetermined period, the competence of the IACHR to receive communications by other States Parties alleging that the former have breached the Convention. The admissibility criteria set by Article 46 include: the exhaustion of local remedies, the presentation of the petitions within six months of the communication of the last decisions on the domestic level, the absence of "another international proceeding" relating to the same subject matter, and, in the case of petitions brought under Article 44, the identification of the petitioner. Furthermore, petitions and communications shall be held inadmissible under Article 47 if they fail to state the facts tending to establish the existence of a violation, if the statements of the petitioner or of the complaining State Party reveal that the case being brought is manifestly ill-founded or "out of order", or if the case is essentially identical with one previously examined by the Commission or another international organism. There is, finally, the possibility of reaching a friendly settlement with the participation of the IACHR. In the case of such a settlement, the Commission shall issue a report summarising the facts and outlining the solution, and that report shall be published (Article 49). If no settlement is forthcoming, the Commission will draw up a report on the facts and make such proposals and recommendations as it sees fit (Article 50).

Turning now to the IACTHR, a first point to be made is that the States Parties and the IACHR have locus standi before the Court, provided that they have previously completed procedures before the Commission (Article 61). Cases may be brought against States Parties which have made a declaration accepting the Court's jurisdiction in all matters concerning the interpretation or application of the ACHR (Article 62.1). If the Court finds one or several violations of the Convention, it:

Shall rule that the injured party be ensured the enjoyment of his right or freedom that was violated. If appropriate, it shall also rule that the consequences of the measure or situation that constituted the breach [...] be remedied and that fair compensation be paid to the injured party (Article 63.1).

In such cases States undertake to comply with the judgment (Article 63.1). Nothing more is said about implementation. 
The mechanism established by the ACHR is relatively old and classical in its operation. What is striking is its blend of liberalism and strictness. While individuals have free access to the IACHR — a liberal solution - the access of States depends on declarations of acceptance made by the respondent States; clearly individuals' petitions are less feared than those of States or the ensuing inter-State conflicts. The IACTHR, on the other hand, remains closed to individuals, at least formally.

\section{(ii) Provision on jurisdiction}

The relevant provision of the American Convention combines a clause on jurisdiction with a prohibition of discrimination. As Article 1.1 prescribes,

[t] he States Parties to this Convention undertake to respect the rights and freedoms recognised herein and to ensure to all persons subject to their jurisdiction the free and full exercise of those rights and freedoms, without any discrimination for reasons of race, color, sex, language, religion, political or other opinion, national or social origin, economic status, birth, or any other social condition.

Accordingly, the States Parties undertake to respect the human rights secured by the Convention and to do so indiscriminately for all persons "subject to their jurisdiction." The latter phrase is not explained further, suggesting that the general rules of international law have to be consulted to establish the meaning of "jurisdiction," and that the jurisdiction of the Convention's organs depends on whether the conduct complained of is attributable to the respondent State and falls under that State's jurisdiction.

\section{(b) The African Charter on Human and Peoples' Rights}

\section{i) General provisions}

The African system too distinguishes between inter-State cases and the communications of others, and here, too, a commission (the ACHPR) and a court (the ACTHR) were established.

Articles 47 to 54 of the African Charter deal with communications addressed by States Parties to other States Parties and alleging breaches of the African Charter. The communicating State may then open an independent negotiating procedure which must yield a solution within three months, failing which that State may unilaterally take the issue to the 
ACHPR (Articles 47 and 48). It may also address itself to the Commission directly, without going through the negotiating phase (Article 49). Such communications will be considered inadmissible, however, if domestic remedies have not been exhausted (Article 50).

If the ACHPR fails to produce a friendly settlement, it must prepare, "within a reasonable period of time," a report recounting the facts and giving its findings. The report shall be transmitted to the States concerned and be communicated to the African Union's Assembly of Heads of States and of Governments, together with "such recommendations as [the Commission] deems useful" (Articles 52 and 53). For each ordinary session of the Assembly, the ACHPR has to prepare a report on its activities which will obviously include information about communications made by States (Article 53).

Articles 55 and following of the African Charter deal with "other" communications, that is, those made by individuals, organisations, and NGOs. These communications are considered if the ACHPR so decides (Article 55) and if they are admissible under the conditions set by Article $56 .^{5}$

If the Commission finds that a communication reveals serious or massive violations, it shall so inform the Assembly of the Union. The Assembly may then request the ACHPR to undertake an in-depth study of the issue and to draw up a factual report together with its findings and recommendations (Article 58).

Finally, according to Article 59 of the Charter, all measures taken in the above context shall remain confidential unless or until the Assembly decides otherwise.

It will now be convenient to turn to the Protocol to the African Charter on the Establishment of an African Court on Human and Peoples' Rights, of 10 June $1998,{ }^{6}$ at its actual stage of development. ${ }^{7}$ This text establishes the ACTHR, the jurisdiction of which extends to:

\footnotetext{
5 They may not be anonymous, nor may they relate to cases already settled according to principles of the UN Charter, the Charter of the African Union, or that of the ACHPR. They must be compatible with the latter two instruments, be written in decent language, not be based exclusively on news disseminated by the mass media, and be presented within a reasonable time after the last decision on the national level. Domestic remedies must, of course, have been exhausted.

6 Council of Europe, op. cit., note 3, p. 595.

7 On present attempts to bring about the merger of the Court with that of the African Union, see Caflisch, L. \& Kamga, M. (2015), “The Peaceful Settlement of International
} 
All cases and disputes submitted to it concerning the interpretation and application of the [African] Charter, this Protocol and any other relevant human rights instrument ratified by the States concerned.

This Court is competent to decide on its own competence (Article 3).

The ACTHR may be addressed (Article 5) by the Commission, by a State having filed a complaint, by a State against which such a complaint has been lodged with the Commission, by the victim's national State, or by African international organizations. Furthermore, the Court "may entitle" relevant NGOs with observer status before the Commission, as well as individuals, to bring cases against States Parties to the Protocol that have specifically accepted the Court's jurisdiction to that effect. In such cases, the Court will have to decide on their admissibility under the conditions set out in Article 56 of the African Charter. ${ }^{8}$

Article 27 of the Protocol provides that the Court may (or may not) find breaches of the Charter and issue orders for reparation, including the payment of fair compensation. Under Article 30, States undertake to comply with judgments within the time limits set by the Court and to bring about their implementation.

As in the case of the European Court of Human Rights (ЕCTHR), the implementation of the African Court's judgments is entrusted to an executive organ, in this case the Executive Council of the African Union (Protocol, Article 29.2). ${ }^{10}$ This differs from the Inter-American system, in which the Court itself is to perform that function.

The mechanism described above uses the Commission as an organ of conciliation and a springboard for inter-State action, and as an instance to deal with other matters, especially individual communications. Following the classical pattern, the African Court can deal only with State claims against other States Parties and claims by African international organisations; specific declarations accepting the Court's jurisdiction by the States concerned are required for cases brought by individuals and NGOs, and procedural conditions must be met.

Disputes in Africa: Present and Future," African Yearbook of International Law, Vol. 20, pp. 361-408.

8 See above, p. 168 and n. 5.

9 See below, pp. 174-175.

10 On this point, see Fédération internationale des ligues des droits de l'homme (2010), Guide pratique: La Cour africaine des droits de l'bomme et des peuples, p. 128. 


\section{(ii) Provisions on jurisdiction}

Article 1 of the African Charter provides that:

[T] he member States of the Organisation of African Unity [now the African Union] Parties to the present Charter shall recognise the rights, duties and freedoms enshrined in [Chapter I of the Charter] and shall undertake to adopt legislative or other measures to give effect to them.

According to the above, the States Parties "recognise" the rights and freedoms secured by Chapter I of the African Charter and "undertake" to adopt "legislative and other measures" to "give effect to them". In other words, the States Parties promise to implement the Charter, a promise that includes a duty to respect its provisions and international responsibility for their violation.

Article 1 remains silent about jurisdiction, however. The ACHPR's Rules of Procedure, which entered into force on 18 August 2010, ${ }^{11}$ are silent as well, as is Article 3 of the Protocol Establishing the African Court, of 10 June 1998. According to that Article, the jurisdiction of the Court extends to all cases and disputes submitted to it concerning the interpretation and application of the Charter, of this Protocol, and of any other relevant human rights instrument ratified by States concerned. Article 3 further provides that if there is a dispute on wether it has jurisdiction the Court shall decide. The Rules of the Court (entered into force on 2 June 2010) ${ }^{12}$ and the 2008 Protocol on the Statute of the African Court of Justice and Human Rights (not in force) ${ }^{13}$ are also silent on the matter.

In his book on the African Charter, Fatsah Ouguergouz expresses the view that the Charter silence silence in this regard will not prevent the Commission from dealing with human rights violations that can be attributed to a State Party although they occurred outside that State's territory. This assertion is buttressed by the practice of the (defunct) European Commission on Human Rights and ECTHR case law. ${ }^{14}$

\footnotetext{
11 www.achpr.org/instruments/rules-of-procedure-2010.

12 Fennell, S. \& Andoni, D. (eds.) (2014). The African Court on Human and Peoples' Rights. Basic Documents. Oisterwijk, Netherlands: Wolf Legal Publishers. p. 75.

13 Brownlie's Documents on Human Rights, $6^{\text {th }}$ ed. (2010). Brownlie, I. \& Goodwin-Gill, G. (eds.). Oxford: Oxford University Press, p. 1050.

14 Ouguergouz, F. (2003). The African Charter on Human and Peoples' Rights. The Hague: Nijhoff, paras. 18-26.
} 
Regarding the jurisdiction of the ACTHR, Ouguergouz explains that since the Protocol is silent on this point as well, it may be concluded that the Court could also deal with violations that occurred in the territory of any State Party to the Protocol. He then points out that Article 3 of that instrument is worded broadly enough to deal on the same terms with violations imputable to a State Party when they have been committed outside the territory of that State. ${ }^{15}$

In conclusion, there are no provisions on the issue examined in this contribution, but some authors suggest that if States Parties commit violations of the Convention outside their territory but under their jurisdiction and control, they can be held responsible for them. General international law and the practice of the ACHPR supports this view.

\section{(C) UN Covenant II on Civil and Political Rights}

\section{(i) General provisions}

Unlike the other instruments examined in this paper, the ICCPR of 16 December 1966 is of potentially universal application. It also differs from these instruments in that it is not endowed with a genuinety apparatus; it is implemented by an organ called the Human Rights Committee of the United Nations (HRC; Articles 28-45 of the Covenant).

Within one year of becoming Parties to the ICCPR, States shall present to the HRC an initial report on the measures taken to implement the Covenant and on the progress achieved. Further reports must be submitted as requested by the Committee.

States Parties to the ICCPR may declare at any time that they recognise the HRC's competence to receive and consider communications regarding violations committed by other States Parties which have made similar declarations (Article 41.1). Such communications must be addressed to the State Party accused of having violated the Covenant. A State so accused

15 Ibid., p. 729. See further Viljoen, F. (2008). "Communications under the African Charter: Procedure and Admissibility: The System in Practice, 1986-2006" in: Evans, M. \& Murray, R. (eds.), The African Charter on Human and Peoples' Rights. The System in Practice, 1986-2006, $2^{\text {nd }}$ ed., Cambridge: Cambridge University Press, pp. 76-138 (107); Bulto, T.S. (2011), "Patching the 'Legal Black Hole': The Extraterritorial Reach of States' Human Rights Duties in the African Human Rights System", South African Journal on Human Rights, Vol. 27, pp. 249-278 (258-260). 
then has three months to provide a clarifying explanation, including references to domestic procedures available and used. If the matter cannot be settled to the satisfaction of the disputing States within a period of six months from the communication, each of them may go before the HRC, which will deal with the issue after having ascertained that domestic remedies have been exhausted. The HRC may also offer its good offices to achieve a friendly settlement. During the examination of the matter by the Committee, the States concerned may be represented before it and make submissions. Within twelve months of the matter being referred to the HRC, the Committee shall draw up a report. If a friendly settlement has been reached, the report will contain a brief statement of the facts and of the solution found. If no compromise has been struck, the report shall consist of a short statement of the facts with the Parties' submissions attached. In any event, the report is communicated to the States Parties concerned (Article 41) and is reflected in the HRC's yearly report to the UN General Assembly (Article 45).

There is another text to be considered: the Optional Protocol to the ICCPR. ${ }^{16}$ By becoming a Party to it, a State recognises the HRC's competence to receive and consider communications made by individuals claiming to have been victims of violations of human rights secured by the ICCPR (Protocol, Article 1). The Committee shall, after having examined the admissibility of the communication and the substance of the matter, ${ }^{17}$ forward its views to the State Party and the individual concerned (Article 5.4). It shall also include, in its Annual Report under Article 45 of the ICCPR, "a summary of its activities under the present Protocol". This summary shall comprise descriptions of the matters that have been reported on under the terms of the Protocol (Article 6).

Such is the general content of reporting duties, which can prove quite unpleasant for State representatives. It consists of a complaint procedure between States with a built-in conciliation phase, ${ }^{18}$ and for States Parties

16 Protocol of 16 December 1966, Council of Europe, op. cit., note 3, p. 51.

17 Communications may not be anonymous and may not constitute an abuse of the right to submit communications or be incompatible with the provisions of the Covenant (Article 3). Their author must have exhausted domestic remedies and the communication may not be the object of another procedure of investigation or settlement (Article 5.2).

18 In cases between States, Article 42 allows the Committee to appoint ad hoc conciliation commissions with the consent of the States directly involved. When these organs have finished their work, but in any event not later than twelve months after having been 
that subscribe to the Protocol, a communication procedure for individuals which entails a certain degree of publicity. It may thus be said that while these features do not amount to full judicial proceedings like those of the other systems examined here, they do have some salutary effects.

\section{(ii) Provision on jurisdiction}

The HRC is not, strictly speaking, a judicial organ, but it does exercise dispute settlement functions the extent of which is determined by Article 2 of the Covenant:

1. Each State Party to the present Covenant undertakes to respect and to ensure to all individuals within its territory and subject to its jurisdiction the rights recognized in the present Covenant, without distinction of any kind, such as race, colour, sex, language, religion, political or other opinion, national or social origin, property, birth or other status.

2. Where not already provided for by existing legislative or other measures, each State Party to the present Covenant undertakes to take the necessary steps, in accordance with its constitutional processes and with the provisions of the present Covenant, to adopt such legislative or other measures as may be necessary to give effect to the rights recognised in the present Covenant.

Paragraph 1 of this text must have served as a model for Article 2.1 of the American Convention of 1969. Accordingly, the comments made regarding that provision also apply here. Paragraph 2 reinforces the first paragraph by prescribing, as does Article 2 of the ACHR, that States Parties must adopt such legislative or other measures as may be needed to give effect to rights guaranteed by the Covenant.

seized, the commissions present a report to the Chairman of the HRC, the contents of which are described in Article 42.7 of the Covenant. Three months later, the State Parties concerned inform the Chairman of the HRC whether or not they accept the report of the ad hoc Commission (Article 42.7.d). 


\section{(d) European Convention on Human Rights}

\section{(i) General provisions}

The oldest yet most sophisticated international mechanism for protecting human rights is, perhaps paradoxically, that provided in 1950 by the ECHR. The European system extends to inter-State cases (Article 33) and individual applications (Article 34) that can be brought before single judges, three-member panels, chambers, and possibly the Court's Grand Chamber. ${ }^{19}$ Respondent States are subject to the Court's jurisdiction by the simple fact of their being Parties to the ECHR.

The admissibility of individual applications depends on the fulfilment of a long list of conditions (Article 35): (i) Applications must be compatible with the provisions of the Convention (such as Article 1); (ii) they may not be manifestly ill-founded; (iii) they may not amount to an abuse of the right of application; (iv) they may not be substantially identical to matters already examined by the Court or submitted to another procedure of international investigation or settlement without containing new information; (v) they must respect the six-month rule (now reduced to three months); ${ }^{20}$ (vi) their author must have exhausted domestic remedies; and (vii) they may not be anonymous.

These conditions are intended to show that the international mechanism is subsidiary to domestic proceedings and to prevent the Court from being swamped by individual applications.

The friendly settlement of claims is permitted by Articles 38 and 39 of the Convention.

Decisions on admissibility and judgments on the merits by single judges, panels, chambers and the Grand Chamber are final under the conditions established in Article 44, ${ }^{21}$ and must be complied with. Their

19 According to Article 31.a, the Grand Chamber shall "determine applications submitted either under Article 33 or Article 34 when a Chamber has relinquished jurisdiction under Article 30 or when the case has been referred to it under Article 43" (request for re-examination of a case already adjudicated by a chamber).

20 Article 4 of Protocol No. 15 of 24 June 2013, European Treaty Series No. 213.

21 Article 44 provides that: " 1 . The judgment of the Grand Chamber shall be final. 2. The judgment of a chamber shall become final (a) when the parties declare that they will not request that the case be referred to the Grand Chamber; or (b) three months after the date of judgment, if reference of the case to the Grand Chamber has not been 
implementation by the respondent State is supervised by the Committee of Ministers of the Council of Europe (Article 46 of the ECHR).

\section{(ii) Provisions on jurisdiction}

Article 1 of the ECHR provides: "Obligation to respect human rights. The High Contracting Parties shall secure to everyone within their jurisdiction the rights and freedoms defined in Section I [Articles 2 to 18] of this Convention".

This provision is completed by Article 56.1 of the Convention, which allows States Parties to make at any time declarations extending the scope of the ECHR to any territories for whose international relations they are responsible. If they have done so, Article 56.4 allows them to accept the competence of the Court to receive and examine individual applications in relation to such territories. ${ }^{22}$ Finally, Article 58.1 enables States having made such declarations to denounce at six months' notice.

In the preparatory work on Article 1 , one finds an observation, made by the representative of Belgium on 25 August 1950 in a plenary meeting of the Assembly of the Council of Europe, according to which:

The right of protection by our States, by virtue of a formal clause of the Convention, may be exercised with full force, and without any differentiation or distinction, in favour of individuals of any nationality,

requested; or (c) when the panel of the Grand Chamber rejects the request to refer under Article 43. 3. The final judgment shall be published". It will be noted, however, that under Article 35.4 of the ECHR, "[t]he Court shall reject any application which it considers inadmissible under [Article 35]. It may do so at any stage of the proceedings [emphasis added]". 22 The full text of Article 56 provides that: " 1 . Any State may at the time of its ratification or at any time thereafter declare by notification addressed to the Secretary General of the Council of Europe that the present Convention shall, subject to paragraph 4 of this Article, extend to all or any of the territories for whose international relations it is responsible. 2. The Convention shall extend to the territory or territories named in the notification as from the thirtieth day after the receipt of this notification by the Secretary General of the Council of Europe. 3. The provisions of this Convention shall be applied in such territories with due regard, however, to local requirements. 4. Any State which has made a declaration in accordance with paragraph 1 of this Article may at any time thereafter declare on behalf of one or more of the territories to which the declaration relates that it accepts the competence of the Court to receive applications from individuals, non-governmental organisations, or groups of individuals as provided by Article 34 of the Convention [individual applications]". 
who on the territory of any one of our States, may have had reason to complain that [their] rights have been violated. ${ }^{23}$

Article 1 does not define the jurisdiction of the ECTHR, or does so in a roundabout way by determining the scope of States Parties' obligation to secure the rights established by the Convention to individuals and, thus, indirectly, the Court's jurisdiction. But such jurisdiction exists only when it is alleged that a Convention State has failed to respect human rights, i. e. when an individual — not his or her national State — contends that the Convention State concerned has breached its international human rights obligations vis à vis that individual. In other words, the Court's power to examine a claim depends not on the (foreign) nationality of the individual victim, but on whether, regardless of his or her nationality, that person's human rights have been violated as a result of the conduct of the organs of a Convention State - even if that State happens to be the individual's national State.

\section{(e) Conclusion}

The above survey shows that States Parties are duty bound to take the measures necessary to secure the rights guaranteed by the relevant international instrument and to take the necessary measures to that effect. Thus jurisdiction is the essential prerequisite for this guarantee and for the international responsibility of States Parties in the event of non-observance, and also for the presentation of individual claims to Convention organs. It is nowhere specified what the human rights treaties mean by "jurisdiction". Thus that expression may be interpreted as being co-terminous with jurisdiction in general international law. Whether this is the case or not may be revealed by the available practice.

\section{The Practice of International Human Rights Organs Relating to Attribution, Responsibility and Jurisdiction}

\section{(a) Practice under the American Convention}

It will be remembered that under Article 1.1 of the ACHR, the rights and freedoms protected by the Convention must be extended by States Parties

23 See Collected Edition of the Travaux préparatoires of the European Convention on Human Rights, Vol. III, p. 260. 
"to all persons subject to their jurisdiction". This formula, which also appears in Article 1.1 of the ECHR, limits the scope of the responsibility of States Parties to persons placed under their control when it is alleged that a Convention provision has been breached. According to a recent commentary of the ACHR, this means that there is jurisdiction, in principle, where the State concerned exercises territorial sovereignty. There are, however, situations where the powers of a State extend beyond its borders, either by virtue of powers conferred on it by the rules of international law, or because it exercises a sort of "control" over foreign territory.

The commentators go on to report that in the framework of the IACHR,

there has not, so far, been any dispute over State jurisdiction ratione loci. All the situations brought before it and characterised as violations occurred on the territories of the respondent States. ${ }^{24}$

Nevertheless, they think that such situations could well arise in the future, as has been the case in other parts of the world. ${ }^{25}$

A precedent can be found, however, in the practice of the IACHR, specifically in the case of Alejandre, Costa, de la Peña and Morales (Cuba). This case related to the shooting down by the Cuban Air Force of two unarmed civilian aircraft in international airspace. The aircraft belonged to the organisation "Brothers to the Rescue", and the Cuban action caused the death of the persons for whom the case is named. The Commission found the complaint admissible and held the State of Cuba responsible. It asked Cuba to investigate the incident, to punish those responsible, and to indemnify the victims families. Cuba did not react.

Concerning the admissibility of the complaints, the Commission had this to say:

[i]n terms of its competence ratione loci, clearly the Commission is competent with respect to human rights violations that occur within

24 MacGregor, E. F. \& Pelayo Müller, C. M. (2014). "Artículo 1", in: Steiner, C. \& Uribe, P. (eds.), Convención Americana sobre Derechos Humanos. Comentario, Bogotá: Temis, pp. 42-68 (60) (author's translation). As an example, the Nicaragua case is cited (Military and Paramilitary Activities in and against Nicaragua (Nicaragua v. United States)), merits, International Court of Justice (ICJ), judgment of 27 June 1986, ICJ Reports 1986, p. 14.

25 See Cyprus v. Turkey, No. 25781/94, [GC], judgment of 10 May 2001, and Ilasscu and Others v. Moldova and Russia, No. 48787/99, [GC], judgment of 8 July 2004. 
the territory of OAS [Organisation of American States] member States, whether or not they are Parties to the Convention. It should be specified, however, that under certain circumstances the Commission is competent to consider reports alleging that agents of an OAS member State have violated human rights protected in the inter-American system, even when the events take place outside the territory of that State. In fact, the Commission would point out that, in certain cases, the exercise of its jurisdiction over extraterritorial events is not only consistent with but required by the applicable rules. The essential rights of the individual are proclaimed in the Americas on the basis of equality and non-discrimination, 'without distinction as to race, nationality, creed, or sex'. Because individual rights are inherent to the human being, all the American States are obligated to respect the protected rights of any person subject to their jurisdiction. Although this usually refers to persons who are within the territory of a State, in certain instances it can refer to extraterritorial actions, when the person is present in the territory of a State but subject to the control of another State, generally through the actions of that State's agents abroad. In principle, the investigation refers not to the nationality of the alleged victim or his presence in a particular geographic area, but to whether, in those specific circumstances, the State observed the rights of a person subject to its authority and control. ${ }^{26}$

In view of the above, it may safely be assumed that if the IACTHR were to be confronted in the future by a situation relating to the admissibility of a claim regarding the conduct of a State outside its territory, it would seek a solution in the general rules on territorial, extraterritorial, and personal jurisdiction. This assumption is based on the clear text of Article 1.1 of the ACHR, on its identity with Article 1 of the ECHR, on the attitude of the IACHR, and on ECTHR case law. ${ }^{27}$

26 Report No. 86/99, Case 11589, 29 September 1999, para. 23 (footnotes omitted). An earlier case that may bear mentioning is that of Comité Haitiano de Derechos Humanos et al., Report No. 51/96, Case 10675 (United States), 13 March 1997, which concerned Haitian refugees who were forced by us vessels on the high seas to return to their point of origin. This situation had to be considered from the angle, not of the American Convention, but of the American Declaration of the Rights and Duties of Man of 1948 (Council of Europe, op. cit., note 3, p. 633), since the United States was not a Party to the former Convention.

27 See below, pp. 167, 175-176, 176-178, 184 et seg. 


\section{(b) The African Charter}

The situation in Latin America seems reasonably clear, unlike that which prevails or has prevailed in Africa. Article 1 of the African Charter is silent on the issue, and one wonders why. Is it because the authors of the Charter overlooked the problem? Hardly, since the European Convention (1950), the American Convention (1969), and the ICCRP (1966) had models to offer. Was it in order to do things differently? If so, why did the African Charter follow these models in other respects? Was it because it was thought that African States would never be accused of breaching human rights beyond the confines of their territories?

Whatever the answers to these questions, they are not provided by conventional texts or by the practice of the African Court. There are opinions of authors, however, some practice of the Commission and, most importantly, a highly relevant advisory opinion the ICJ.

In this regard, attention is drawn to three communications addressed to the ACHPR. The first related to a complaint by the Democratic Republic of the Congo directed at Burundi, Rwanda, and Uganda, which was the first-ever inter-State communication declared admissible by the Commission. ${ }^{28}$ It concerned complaints about human rights violations allegedly committed on its territory, brought by an African State Party to the African Charter against other States Parties to that instrument. The Democratic Republic of the Congo objected to the occupation of its territory by the armed forces of Burundi, Rwanda, and Uganda and the ensuing violations of individual and collective rights protected by the Charter. The ACHPR held the communication to be admissible for reasons not directly related to the topic of this contribution. But in so doing, it recognised that the three respondent States had exercised jurisdiction on Congolese territory and could therefore be held responsible for human rights violations committed by their armed forces.

Another communication, presented by an NGO and directed at six African States ${ }^{29}$ related to an embargo decreed by those States against Burundi. Here the ACHPR concluded that States had "extraterritorial" duties to respect human rights and had to abstain from denying human rights to individuals and groups on the territory of third States.

\footnotetext{
28 D. R. of Congo v. Burundi, Rwanda and Uganda, communication 227/99 (2003).

29 Association pour la sauvegarde de la paix au Burundi v. Kenya, Rwanda, Tanzania, Zaire and Zambia, communication 157/96 (2003).
} 
The third case concerned a subject of Djibouti who accused his own country of human rights violations allegedly committed by that State on its own territory. The ACHPR declared the communication inadmissible. ${ }^{30}$ It is interesting in the present context, however, because the Commission took a position on the extraterritorial obligations of States Parties in human rights matters, stating that:

Circumstances may obtain in which a State assumes obligations beyond its territorial jurisdiction such as when a State assumes effective control of part of another State [...] or where the State exercises control or authority over an individual $[\ldots]^{31}$

The Commission added that:

A complaint must establish a sufficient connection between the alleged violation and the respondent State before the Commission can proceed to invoke the obligations of that State under the Charter with a view to assessing whether such obligations were breached. ${ }^{32}$

Finally, the Commission assented that:

[f]or purposes of admissibility a complainant can establish the sufficient connection by proving that he or she was under the territorial jurisdiction, or effective control or authority of the respondent State when the alleged violation occurred. A classic example of the latter is the case of a State occupying part of the territory of another State as was held by the International Court of Justice in the Case Concerning Armed Activities on the Territory of the Congo. ${ }^{33}$

From the above, it is not unreasonable to deduce that the Pan-African human rights organisms, including in all probability the African Court, would admit that States Parties are responsible not only for human rights

\footnotetext{
30 Mohammed Abdullah Saleh Al-Asadv. Republic of Djibouti, communication 383/10 (2014).

31 Ibid., para. 63.

32 Ibid., para. 135. For the case between Congo and Uganda, see judgment of 19 December 2005, ICJ Reports 2005, p. 168.

33 Ibid., para. 136.
} 
violations on their own territory, but also for those committed abroad in situations under their authority or control. ${ }^{34}$

\section{(C) UN Covenant on Civil and Political Rights}

Article 2.1 of the ICCPR distinguishes itself by its ambiguity. It prescribes that States Parties to the Covenant undertake to respect and protect the rights guaranteed "to all individuals within [their] territory and subject to [their] jurisdiction". A literal, i. e. cumulative interpretation of this passage would suggest that the guarantee extends only to individuals present on the State's territory at the time of the violation and subject to its jurisdiction as well. As noted by one author, ${ }^{35}$ this would mean, for instance, that a national of a State Party could not claim the right, protected by Article 12.4 of the ICCPR, not to be "arbitrarily deprived of the right to enter his own country." It would generally remove from the scope of the Covenant all situations involving individuals outside the State's territory but falling under its jurisdiction.

The drafting history shows that the text originally proposed covered the rights of individuals subject to the respondent State's jurisdiction, following the example set by Article 1 of the ECHR and Article 1 of the ACHR. The United States proposed to replace that text with the words "within its territory", perhaps in order to protect itself from undesirable consequences resulting from its activities abroad, as exemplified by the case of the Haitian Human Rights Committee. ${ }^{36}$ Finally, both elements, connected by the conjunction "and", were included in Article 2.1 of the ICCPR. An American author has suggested that the word "and" had a "disjunctive" meaning and had to be interpreted as meaning "or". ${ }^{37}$ This view has been criticised as implying that respondent States Parties are responsible for all violations committed on their territory, which is not the case. For example,

34 The author wishes to thank Dr. Fatsah Ouguergouz, judge of the African Court on Human and Peoples' Rights, and Dr. Mutoy Mubiala, of the Office of the UN Commissioner on Human Rights, for their help in obtaining information on the situation in Africa.

35 Nowak, M. (2005). UN Covenant on Civil and Political Rights. CCPR Commentary, $2^{\text {nd }}$ rev. ed., Kehl a. Rh., N. P. Engel, No. 27, p. 43.

36 See above, note 26.

37 Buergenthal, T. (1981). "To Respect and to Ensure: State Obligations and Permissible Derogations", in Henkin, L. (1981). (ed.) The International Bill of Rights. The Covenant on Civil and Political Rights, New York: Columbia University Press, pp. 72-91 (74). 
they are not responsible for actions by intergovernmental organisations or occupying powers. ${ }^{38}$

Whatever controversies may have arisen over the meaning of Article 2.1 of the ICCPR, General Comment 31 ("Nature of the General Legal Obligation on States Parties to the Covenant") seems to favour the "disjunctive" view:

States Parties are required by article 2, paragraph 1 , to respect and to ensure the Covenant rights to all persons who may be within their territory and to all persons subject to their jurisdiction. This means that a State Party must respect and ensure the rights laid down in the Covenant to anyone within the power or effective control of that State Party, even if not situated within the territory of the State Party. As indicated in General Comment 15 adopted at the twenty-seventh session (1986), the enjoyment of Covenant Rights is not limited to citizens of States Parties but must also be available to all individuals, regardless of nationality or statelessness, such as asylum seekers, refugees, migrant workers and other persons, who may find themselves in the territory or subject to the jurisdiction of the State Party. This principle also applies to those within the power or effective control of the forces of a State Party acting outside its territory, regardless of the circumstances in which such power or effective control was obtained, such as forces constituting a national contingent of a State Party assigned to an international peace-keeping or peace-enforcement operation. ${ }^{39}$

This passage shows that the ICCPR no longer wishes to apply Article 2 literally and instead relies on the object and purpose of that text, as it is authorised to do under Article 31.1 of the Vienna Convention of 23 May 1969 on the Law of Treaties. ${ }^{40}$

The decisive element on this issue will, however, be found in the ICJ's advisory opinion on the Legal Consequences of the Construction of a Wall in the Occupied Palestinian Territory. ${ }^{41}$ In that case, the Court was asked whether the international human rights instruments to which Israel was a Party, and particularly the ICCPR, were applicable within the occupied territory.

\footnotetext{
38 Nowak, op. cit., note 35, p. 43; for other cases, see also op. cit., pp. 859-862.

3929 March 2004, un Doc. CCPR/C/21/Rev. 1/Add.13.

40 United Nations Treaty Series, Vol. 1155, p. 331.

41 Opinion of 9 July 2004, ICJ Reports 2004, p. 136 (paras. 107 to 111).
} 
As has been pointed out and as the Court stated, Article 2 - the relevant text on this matter- was subject to two interpretations: as protecting only persons in that territory and subject to the territorial State's jurisdiction, or as extending to outside territories subject to that State's jurisdiction.

The Court opted for the latter solution, invoking first, the object and purpose of the Covenant and, second, the practice of the HRC. On the latter, the Court had this to say:

The Committee has found the Covenant applicable where the State exercises its jurisdiction on foreign territory. It has ruled on the legality of acts by Uruguay in cases $^{42}$ of arrests carried out by Uruguayan agents in Brazil or Argentina [...] It decided to the same effect in the case $^{43}$ of the confiscation of a passport by a [sic] Uruguayan consulate in Germany. ${ }^{44}$

The Court also referred to the preparatory work of the Covenant, explaining that when its drafters adopted the text of Article 2, they had not intended to let States dodge their obligations when exercising jurisdiction outside their national territory. Their intention was merely to prevent persons residing abroad from asserting vis-à-vis their State of origin rights that were within the competence not of that State, but of the State of their residence. Finally, the Court invoked communications made by Israel to the ICCPR. While Israel took the position in 1998 that the Covenant "did not apply directly to the current situation in the occupied territories", the Committee expressed doubts on that view. When the Committee again faced Israel's position on this issue in 2003, it decided that:

In the current circumstances, the provisions of the Covenant apply to the benefit of the population of the Occupied Territories, for all conduct by the State Party's authorities or agents in those territories that affect the enjoyment of rights enshrined in the Covenant and fall within the ambit of State responsibility of Israel under the principles of public international law. ${ }^{45}$

\footnotetext{
42 Case No. 52/79, Lopez Burgos v. Uruguay; case No. 56/79, Lilian Celiberti de Casariego v. Uruguay.

43 Case No. 106/81, Montero v. Uruguay.

44 ICJ Reports 2004, p. 136 (para. 109).

45 Ibid., p. 180, citing document CCPR/CO/78/ISR, para. 11.
} 
These passages of the ICJ's advisory opinion, together with the ICCPR's practice and especially General Comment 31, lead to the clear conclusion that this Committee, too, applies the general rules of international law on the matter.

\section{(d) Case Law of the European Court of Human Rights}

Much of the ECTHR's practice on the issue has already been examined elsewhere in some detail ${ }^{46}$ so it will be sufficient to recall the salient features of that practice.

A first feature is that the jurisdiction of the Strasbourg Court is essentially territorial, i. e. centred on situations and events localised on the respondent State's territory. That State may, however, withdraw part of its territory from the scope of the Convention pursuant to its Article 56. ${ }^{47}$ If it does not do so, the respondent State retains jurisdiction and will be responsible for violations committed on its territory, even if it no longer controls the area where the conduct complained of took place. Indeed, that State may have decided not to invoke Article 56 because it does not wish to admit that it has lost control over the area concerned. ${ }^{48}$

A second feature of the Court's case law is that jurisdiction under Article 1 of the ECHR can flow not only from territorial sovereignty, but also from lesser degrees of dominance such as occupation, "effective overall control", or "global control" ${ }^{49}$ as demonstrated in the Northern Cyprus cases. Other cases show, however, that some limited manifestations of power are insufficient to produce overall or global control. ${ }^{50}$ In later instances, the dominance required appears to have been whittled down to

\footnotetext{
46 On this practice, see among others Caflisch, L. (2015). "The Iraqi Cases: Further Elements and Thoughts Concerning Jurisdiction under Article 1 of the European Convention on Human Rights," in Wolfrum, R., Seršić, M. \& Sošić, T. M. (eds.) Contemporary Developments in International Law. Essays in Honour of Budislav Vukas, Leiden, Brill / Nijhoff, pp. 431-457; and, by the same author, "The Law of the Sea and the Internationally Protected of Human Rights" in: Sainz- Borgo, J. C. (ed.). Liber Amicorum Gudmundur Eiriksson (forthcoming).

47 For the text of Article 56, see note 22.

48 Assanidze v. Georgia, No. 71503/01, [GC], judgment of 8 April 2004.

49 Loizidou v. Turkey (preliminary objections), No. 15318/89, judgment of 23 March 1995; Cyprus v. Turkey, No. 25781/94, [GC], judgment of 10 May 2001.

50 The case of Bankovic and Others v. Belgium and Others, No. 52207/99, [GC], decision of 12 December 2001, shows that a simple bombing, though spelling death and destruction, is insufficient to produce control.
} 
"control", or even less: simple shooting from a military helicopter hovering in foreign airspace was held sufficient to generate jurisdiction under Article 1 of the ECHR. ${ }^{51}$

A third feature is that certain types of jurisdiction are dissociated altogether from the traditional concept of territoriality. They derive from rules of international law on jurisdiction: the jurisdiction exercised by flag States of vessels at sea, aircraft in airspace or space vessels in outer space; the jurisdiction arising from the activities of diplomatic and consular officers and other agents abroad; and the jurisdiction resulting from the consent of the territorial sovereign. All in all, it may be said that the Court's case law conforms to the general rules of international law governing jurisdiction.

\section{(a) The Banković, Al-Skeini, and Behrami cases}

Among the cases contributing to the practice of the ECTHR, that of Bankovic and Others v. Belgium and Others ${ }^{52}$ is of particular relevance because it summarises the Court's case law on jurisdiction and, in particular, because of the following passage found in its decision:

The Convention is a multilateral treaty operating, subject to Article 56.2 of the Convention, in an essentially regional context and notably in the legal space (contexte juridique) of the Contracting States. The [Federal Republic of Yugoslavia] clearly does not fall within this legal space. The Convention was not designed to be applied throughout the world, even in respect of the conduct of Contracting States. Accordingly, the desirability of avoiding a gap or vacuum in human rights' protection has so far been relied on by the Court in favour of establishing jurisdiction only when the territory in question was one that, but for the specific circumstances, would normally be covered by the Convention. ${ }^{53}$

The Court seems to have thought at that time that its jurisdiction was confined to events and situations in the European "legal space". Subsequently, however, this idea seems to have been superseded, particularly in relation to cases connected with events during the second intervention

51 Pad and Others v. Turkey, No. 60167/00, decision of 28 June 2008.

52 Above, note 50. For the facts of the case, see Caflisch, op. cit., note 46.

53 See Banković decision (above, note 50), para. 80. 
in Iraq, in which the Court assumed jurisdiction over the activities of occupying and other States.

Hassan v. United Kingdom ${ }^{54}$ is a second case deserving attention, as the ECTHR, in its judgement summarised its views on the principles governing non-territorial jurisdiction by referring to the earlier case of Al-Skeini. ${ }^{55}$ In that case it had found that the applicant's family members who were killed had been under the jurisdiction of the occupants, specifically the United Kingdom, which was responsible for the maintenance of security in Southeastern Iraq at the relevant time, and because the killings had occurred in the course of British security operations. This being so, it was unnecessary, according to the Court, to establish whether jurisdiction also resulted from effective military control. The elements in question further seemed to indicate that the United Kingdom was far from exercising "effective control" over the territory it occupied in Southeastern Iraq. ${ }^{56}$ Accordingly, Al-Skeini showed that to justify the exercise of jurisdiction by the Court, it was not even necessary to show the existence of "effective control" over foreign territory. It was sufficient to establish the responsibility of a State for the maintenance of order in that place (para. 75).

Possibly the most interesting of this series of cases are those of Behrami v. France and Saramativ. France, Germany and Norway. ${ }^{57}$ Both of these cases related to the conduct of KFOR (Kosovo Force) and UNMIK (United Nations Interim Administration Mission in Kosovo), two organs established under Security Council Resolution 1244 (1999). The Bebrami case concerned two boys who were playing in a field that had not been cleared of land-mines. When a mine exploded, one of the boys was killed and the other was injured. The responsibility for mine clearance in the area lay first with KFOR and later with UNMIK. In the case of Saramati, an individual was arrested by the police under a mandate issued by the (Norwegian) KFOR commander, because he was suspected of connivance with armed groups in the Kosovo/Macedonia border area, and of attempted murder. He was detained for more than a year and then released. In Behrami, the claim related to a violation of the right to life (Article 2 of the ECHR), and in Saramati a breach of Article 5 (Right to liberty and security) was alleged.

\footnotetext{
54 No. 29750/09, [GC], judgment of 16 September 2014, paras. 74 to 80 .

55 No. 55721/07, [GC], judgment of 7 July 2011, paras. 130 to 142.

56 Case cited in the preceding note.

57 Nos. 71412/01 and 71866/01, [GC], decision of 31 May 2007.
} 
The ECTHR held the application to be inadmissible (Decision, paras. 121 to 152). It found that the conduct complained of was not imputable to the respondent States. According to a technical and military agreement, the security mandate of KFOR included the detention of persons. Its mine-clearance mandate resulted from Article 9.e of Resolution 1244. The control of these activities remained with KFOR until UNMIK could take over, which it did by October 1999 at the latest, i. e. before the Behrami incident. This meant that KFOR could detain persons under its security mandate and that de-mining fell under the mandate of UNMIK (para. 125).

The Court found that the conduct complained of was attributable to the United Nations. In support, the Grand Chamber pointed out that Security Council Resolution 1244 allowed the presence of an international security force in Kosovo. That force acted on the basis of Chapter VII of the UN Charter and of a delegation by the Council. The essential issue was whether or not the ultimate decision making power and control lay with the Security Council. A chain of command reached from the Council down to KFOR and NATO. The multinational brigades were led by an officer of the "leading nation" of the operation in question. That officer was placed under the orders of the KFOR commander, who was in turn subordinated to NATO. As KFOR lawfully exercised functions delegated to the Security Council in Chapter VII of the Charter of the United Nations, its conduct was in principle attributable to that Organisation. Unlike KFOR, UNMIK was placed directly under the Security Council's authority and the alleged omission was imputable to the UN as well (paras. 132 to 143).

Regarding the Court's jurisdiction ratione personae, the Grand Chamber began by noting that the United Nations was an intergovernmental organisation endowed with an international legal personality separate from that of its member States and that it was not a Party to the ECHR. In Bosphorus Airways v. Ireland, ${ }^{58}$ the Court had found that that Convention did not prevent its States Parties from transferring sovereign powers to the European Union, an organisation of which they were members, but that such States would remain accountable for the behaviour of its organs, even if that behavior was necessary to discharge international obligations. If such conduct was the result of international obligations resulting from the State's membership in the intergovernmental organisation, and if the latter provided protection at least equivalent to that offered under the

58 No. 45036/98, [GC], decision of 30 June 2005. 
Convention, there was a presumption that the State had not breached the Convention. If the protection offered was clearly inadequate, however, that presumption was reversed (paras. 144 to 152).

Concretely, the issue was whether the Court had jurisdiction ratione personae to examine the conduct of States acting on behalf of the United Nations and to determine the nature of relations between Strasbourg and the United Nations acting under Chapter VII of its Charter. All States Parties to the ECHR were UN members as well, and one of the Convention's objectives was to ensure the protection of the rights guaranteed by the Universal Declaration of Human Rights. ${ }^{59}$ What is even more important is the binding nature of the UN's basic objective and of the powers of the Security Council under Chapter VII, which allow the Organisation to meet its objective. The primary goal of the United Nations is the preservation of world peace and international security. Although he makes an important contribution respect for human rights to world peace, the Security Council's primary task is that of reaching its goal through coercive measures, which is an exception to the prohibition of the unilateral use of force, a task that is now a precept of customary international law.

In the circumstances prevailing in Kosovo, Chapter VII allowed the Council to react to the conflict by establishing KFOR and UNMIK in accordance with Resolution 1244. Such measures taken in the framework of that Chapter are of great importance for maintaining world peace and international security, and their effectiveness depends on the support of member States. Thus the ECHR cannot be read in a way that would allow the Court to question activities covered by Council resolutions. Such control by the ECTHR could also lead to the formulation of conditions for the implementation of resolutions that are not provided for by the latter. The above reasoning applies equally to voluntary acts performed by States, such as the approval of resolutions by permanent members of the Council or the contribution of military contingents. Though such acts are not always based on membership obligations, their performance may be essential for the functioning of the Security Council and the preservation of peace and security by the United Nations.

The applicants had argued, however, that the protection of fundamental rights by KFOR was in no way equivalent to that offered by the ECHR as defined in the Bosphorus case, and that circumstances reversed

59 Declaration of 10 December 1948, in: Council of Europe, op. cit., note 3, p. 11. 
the presumption of behaviour in conformity with the Convention. The Grand Chamber found that the present cases differed from the situation in Bosphorus. In the latter, the conduct challenged was the confiscation by an Irish Minister acting on Irish territory of an airplane leased by the applicant company, which was why the Court's jurisdiction ratione personae suffered no doubt. By contrast, in the present case, the actions of KFOR and UNMIK did not take place on the territory and the behest of the respondent State. The actions of UNMIK and KFOR were directly attributable to the United Nations.

The decision examined here has not been greeted by much enthusiasm. It would seem, however, that it is justified by cogent practical considerations. If action taken by national contingents contributed by member States to Chapter VII operations could be challenged before the Strasbourg Court by individuals of any nationality and in almost any situation, this could eventually mean the death knell of such contributions, for what European State would take the risk of facing judicial challenges at any time?

\section{(b) Recent cases}

A first case in this series is Abdul Wahab Khan v. United Kingdom, ${ }^{60}$ which concerned a Pakistani student in the United Kingdom whose residence permit had been cancelled on account of alleged Islamist activities and who had left the country voluntarily but appealed the decision of exclusion before the British courts. Having been unsuccessful, he turned to the ECTHR, complaining of violations of Articles 2, 3, 5, 6 and 8 of the ECHR regarding the right to life, the prohibition of torture, the right to liberty, the right to a fair trial and the right to respect for private and family life. Before dealing with these grievances, the Court examined whether the applicant had been placed under the jurisdiction of the United Kingdom and consequently fell under the Court's jurisdiction. It found that, having returned to Pakistan, he had not, and therefore ruled that the application was inadmissible (para. 24).

In its decision, the Court pointed out that the jurisdiction of a State was mainly territorial. Two principal exceptions to the principle had been recognised, however: "State agent authority" and "effective control over an area" by another State. In the present case, the applicant had voluntarily

60 No. 11987/11, decision of 28 January 2014. 
returned to Pakistan, so neither exception applied, in particular because the applicant did not complain of measures taken by the British diplomatic or consular authorities in Pakistan and because he was able to live freely in his country without any interference from British authorities (para. 25).

An important recent case was that of Hassan v. United Kingdom, already referred to ${ }^{61}$ the main issue of which was the applicability to the applicant of Article 5 of the European Convention, i. e. the right to liberty and security. Another issue was whether the applicant's brother had been, at the critical time, under British jurisdiction, in the sense of Article 1 of the Convention.

The essential facts of the case were that, before the second invasion of Iraq the applicant had worked in the national secretariat of the Ba'ath Party and served as a general in the Al-Quds Army, living in Umm Qasr, south of Bassorah. When the British Army occupied the area and began to arrest $\mathrm{Ba}$ 'ath Party officials, he and his family went into hiding, leaving the applicant's brother to watch the family house.

On 23 April 2004, British armed forces went to that house to arrest the applicant. Not finding him there, they arrested his brother and brought him to a camp run jointly by them and the United States Army, where they registered him as a prisoner of war, detained and interrogated him, and apparently released him about ten days later. According to the applicant, his brother did not contact him after being released, but a cousin informed him that a body had been discovered carrying an identity card and a piece of paper mentioning the name of that cousin. The applicant identified the body, which had been pierced by eight bullets, as being that of his brother.

The applicant then brought the matter before the British High Court, requesting an enquiry and compensation. His request was rejected, however, because the victim did not come under the sovereignty and jurisdiction of the United Kingdom. The matter ended up in Strasbourg, where the applicant complained of a breach of Article 5, in particular (Right to liberty), his brother having been found dead later on in specified circumstances.

Before turning to the merits of the case, the Court's Grand Chamber examined whether the applicant's brother had been under British jurisdiction at the time of the alleged violations. Referring to its judgment in Al-Skeini, mentioned above, the Grand Chamber recalled that if a person was killed between 1 May 2003 and 28 June 2005 in the course of an

61 See above, note 54. 
operation in Southeastern Iraq where British troops were mandated to maintain security, it was unnecessary to decide whether that person was under British sovereignty and jurisdiction on account of effective military control exercised by the United Kingdom. In Al-Skeini, the United Kingdom had been far from exercising such control over the territory occupied by its forces. The present case related to an earlier period, before the end of active hostilities and the beginning of occupation, and also before, in which the United Kingdom assumed responsibility for the security of Southeastern Iraq. The Grand Chamber again found it unnecessary to decide whether the United Kingdom had effective control over the area, as it found another reason for concluding that that State had jurisdiction over the applicant's brother (para. 75).

Following his arrest by British troops on 23 April and until his arrival at the camp, the brother of the applicant was under the troops' physical control. Though admitting that the arrest of the victim was effected by State organs acting extraterritorially, the respondent State argued that such conduct would not be attributable to it in a period of armed international conflict and in an area where the organs of a State Party to the Convention other than the occupant were active as well, and where these organs had to act in accordance with the rules of humanitarian international law (para. 76).

The Grand Chamber rejected this argument and pointed out that Al-Skeini also stemmed from a period when human rights law and international humanitarian law applied concurrently. The ECHR should not be interpreted in isolation, but as far as possible in conformity with other rules of international law. This applied to Article 1 as well as to the other provisions of the Convention (para. 77).

The respondent State further contended that following the arrival of the applicant's brother at the camp, jurisdiction had passed from the United Kingdom to the United States. The Grand Chamber found, however, that under the agreements governing the administration of the camp, the applicant's brother was under the authority and control of the United Kingdom. Pursuant to those agreements, he was held as a British prisoner, and it was up to British authorities to classify their prisoners under the Third and the Fourth Geneva Conventions ${ }^{62}$ and to decide on their further

62 Convention Relative to the Treatment of Prisoners of War and Convention Relative to the Protection of Civilian Persons in Time of War. 
detention or their release. The prisoner was released after interrogation. It is true that certain aspects of the detention in this camp were dealt with by US troops, but this did not cancel British authority and control over all aspects of detention relevant for the applicant's claim under Article 5 of the ECHR (paras. 77 to 78 ).

The above considerations led the Grand Chamber to reject the applicant's claim based on Article 5. This judgment is interesting in that it fully supports the Court's earlier findings in Al-Skeini. It no longer rests on the notion of effective military control exercised over the relevant area, but on the concept of specific powers of decision and control, and on the power to release the detainee. This certainly confirms the erosion of territoriality and the corresponding enlargement of extraterritorial jurisdiction in the Court's case law.

The next case, Jaloud v. Netherlands, ${ }^{63}$ concerns an incident involving Dutch troops taking part in the International Stabilisation Force for Iraq from July 2003 to March 2005. These troops were part of the Multinational Division, which was headed by a British officer but remained under full Dutch control. Their operations were governed by a Memorandum of Understanding between the Governments of the United Kingdom and of the Netherlands which included Rules of Engagement for the Dutch soldiers. There was also a contingent of Dutch Military Police operating in Iraq, with its own chain of command and headed by the Prosecutor's Office of the Arnhem District Court.

On 21 April 2004 an unknown vehicle was approaching a checkpoint north of Ar-Rumaytah in Southeastern Iraq. Shots were fired from this vehicle at the Iraqi soldiers manning the checkpoint, but no one was hurt. A military patrol of Dutch soldiers was alerted and appeared at the checkpoint. Soon thereafter a Mercedes vehicle approached the checkpoint at high speed. It hit some barrels but continued moving forward, and was fired at by the leader of the Dutch patrol and by Iraqi soldiers. The son of the applicant, riding in the car, was killed. A team of Dutch Military Police then appeared, collected evidence, and confiscated the guns of the Dutch patrol leader and the Iraqi commander of the checkpoint. The victim's body was taken to a hospital, where an autopsy revealed the presence of metallic fragments. The witnesses of the incident were questioned, and their answer indicated that the driver of the Mercedes had not

63 No. 47708/08, [GC], judgment of 20 November 2014. 
recognised the checkpoint; the patrol leader had thought that shots had been fired from the vehicle and had responded.

The case then was brought before the Prosecutor's Office of the Arnhem District Court, which closed its investigation in June 2004, holding that the victim had probably been killed by an Iraqi soldier rather than the leader of the Dutch patrol, who could in any event have invoked selfdefence. The Arnhem Appeal Court upheld the District Court's decision, and the case went to Strasbourg, where the applicant claimed a violation of the procedural aspect of Article 2 (Right to life) of the Convention due to the enquiry's lack of thoroughness and independence. The respondent State argued that the victim did not fall under its jurisdiction.

The Grand Chamber ruled that it had jurisdiction and that Article 2 had been breached. Regarding the issue of jurisdiction, it began by summarising the Court's findings in Al-Skeini: A State can exercise jurisdiction extraterritorially by performing, with the agreement of a foreign government, some or all of the functions normally assumed by the territorial sovereign. When its organs apply force outside its own territory, it can also subject an individual to its extraterritorial jurisdiction. A further exception to the principle of the territoriality of jurisdiction can be seen in the fact that a State, by the lawful or unlawful use of force, exercises effective control over an area outside its territory (para. 139).

In the present case, the Netherlands mainly contended that authority did not lie with it but with the United States or the United Kingdom, which also exercised authority over the Dutch contingent (para. 140). The Grand Chamber began by pointing out that, by itself, the status of an occupant power in the sense of Article 42 of the 1907 Hague Regulations on Land Warfare ${ }^{64}$ was not decisive (para. 142). The fact that a decision or order of a foreign State was executed was not sufficient to release the executing State from its obligations under the ECHR. That State had not freed itself from responsibility and jurisdiction in the sense of Article 1 of the Convention by arguing that its troops were placed under British command, considering that the Netherlands had asserted that it retained "full command" over them (para. 143).

According to the Grand Chamber, Security Council Resolution 1483 (2003) revealed the presence in Iraq of armed contingents of several UN members working under an "authority" (the "Coalition Provisional

64 See Parry, C. (ed.). Consolidated Treaty Series, Vol. 205, 1907, p. 289. 
Authority") formed by the United States and the United Kingdom. While the Resolution reaffirmed the "sovereignty and territorial integrity of Iraq", it requested the participating member States, whether occupants or not, to meet their obligations under international law and, in particular, under the 1949 Geneva Conventions and the Hague Regulations of 1907 on Land Warfare (para. 144).

In practice the activities of the multinational force were governed by a series of memoranda of understanding and rules of engagement regulating the relations between different contingents. According to a letter from the Foreign Minister of the Netherlands to the Dutch Parliament, the Government retained full command over its contingent in Iraq. As a result of the relevant Memorandum of Understanding and extracts from it relating to the Southeastern area, contingents other than those of the "leading nations" received daily orders from foreign commanding officers, yet the contributing States remained free in their implementation of the memoranda and the rules of engagement. The Government of the Netherlands issued an aide-mémoire and instructions on the conduct of its troops (paras. 146 to 148).

Even though the Dutch troops were stationed in Southeastern Iraq and placed under the command of a British officer, the Netherlands was responsible for maintaining security in the area - to the exclusion of other participating States - and retained full authority over its forces. The fact that the checkpoint was nominally manned by Iraqi troops was not decisive, since these troops were subordinated to and supervised by coalition officers (paras. 149 to 150).

On the basis of these elements, the Grand Chamber was unable to conclude that the Dutch troops had been placed at the disposal of any other power, be it Iraq or the United Kingdom, or that they were exclusively commanded and controlled by such a power (para. 151).

The applicant's brother died when the vehicle in which he was riding was fired at from a checkpoint commanded by a Dutch officer. That checkpoint had been established, pursuant to Security Council Resolution 1483 (2003), to restore stability and security in the area. The performance of this function amounted to an exercise of Dutch jurisdiction in the sense of Article 1 of the ECHR (paras. 152 and 153).

The above description shows that the conditions for exercising extraterritorial jurisdiction in foreign territory have continuously weakened as a result of the Hassan and Jaloud cases discussed above. It seems clear today that, if the armed forces of a Convention State are in control of the 
specific event or situation, even if they are neither occupants nor in exclusive control of the area in which the relevant event has occurred, the sending State has jurisdiction under Article 1 of the ECHR. This being the case, the ECTHR seems to have stretched the concept of extraterritorial jurisdiction to its extreme limit, a limit that was perhaps easy to justify in the Jaloud case, considering the passivity of the Dutch military and judicial authorities.

Another case to be evoked here, Perez. v. Germany, ${ }^{65}$ differed significantly from those described above. The issue, here, was whether a State Party to the ECHR exercised and was therefore responsible for "sovereignty" and "jurisdiction" over human rights violations allegedly committed on its territory by an intergovernmental organisation. The case concerned the dismissal of an employee of the United Nations Development Programme (UNDP) in Bonn, Germany. As the procedural devices available within the UN did not bring the desired relief to the complainant, the latter turned to the Strasbourg Court, alleging violations of Article 6 (fair trial) of the ECHR and claiming that the territorial State, Germany, was responsible, a State over which the Court had jurisdiction under Article 1 of the Convention. The reason underlying this argument was the fact that the UN and its agencies could not be brought before the Court since they were not Parties to the Convention.

For the Court, the mere fact that the action leading to the complaint took place in Germany did not bring the case under its jurisdiction in the sense of Article 1. The Court moreover observed that the German courts had abstained from intervening directly or indirectly $g$ in the case. It was true, however, that the headquarters State, when granting immunity to an international organisation, had to ensure that the latter granted "equivalent" legal protection to its employees. ${ }^{66}$ For certain reasons, the decision explains, the Court left open the question of whether the protection offered by the UN was equivalent, finding that the applicant could in any event have addressed herself to the German Constitutional Court but had failed to do so (paras. 69 to 98).

In the present context, the Perez case is of interest, not so much on account of the problem of the immunity of intergovernmental organisations, but because it shows that the responsibility and jurisdiction of a State are not a given when in reality the control over an armed operation on the

\footnotetext{
65 No. 15521/08, decision of 6 January 2015.

66 Waite and Kennedy v. Germany, and Beer and Regan v. Germany, Nos. 26083/94 and 28934/95, [GC], judgments of 18 February 1999.
} 
territory of a State, Party or not to the Convention, lies not with that State, but with an intergovernmental organisation such as the UN. This could be the case where an operation is directly conducted and controlled by the organisation, which is not itself a Party to the ECHR and cannot, therefore, be brought before the Court. But for the reason already mentioned, i. e. the imperative of offering a complete and effective protection of human rights, the Court will not readily concede that such an operation was fully imputable to the organisation, to the exclusion fo any responsibility or jurisdiction on the part of the contingents of participating States Parties. ${ }^{67}$

The last case to be mentioned, Pisari v. Republic of Moldova and Russia ${ }^{68}$ relates to the shooting of a young Moldovan by a Russian soldier in the "security zone" separating Moldova from Transnistria. The zone was established to monitor the implementation of an agreement ending the military conflict in the area; it was manned by military personnel from Moldova, Transnistria, and Russia. A case was eventually brought by the victim's parents to the ECTHR against Russia, which had immediately moved the perpetrator back to its territory and instituted an investigation clearing him of all charges. The Court found Russia to be responsible for a substantive and a procedural violation of Article 2 (Right to life) of the ECHR. Before reaching that conclusion, it examined the admissibility of the claim.

In that context, the ECTHR, citing Al-Skeini and Jaloud, recalled that

in certain circumstances the use of force by a State's agents operating outside its territory may bring the individual thereby brought under the control of the State's authority into the State's Article 1 jurisdiction $[. .$.$] . This may include the exercise of extraterritorial jurisdiction$ by a Contracting State when, in accordance with custom, treaty or other agreement, the authorities carry out executive functions on the territory of another State [...]. In the present case, the checkpoint in question, situated in the security zone, was manned and commanded by Russian soldiers in accordance with the agreement putting an end to the military conflict in the Transdnistrian region of Moldova [...] (para. 33 of the judgment).

67 This is true except in operations directly undertaken by the Security Council under Articles 42 and following, at least as long as the agreements concluded between the Council and the State contributing armed forces do not attribute substantial power in their management to the national State.

68 No. 42139/12, judgment of 21 April 2015. 
Accordingly, the victim had been under Russian jurisdiction. The case considered here is a classical instance of the exercise by a State of extraterritorial jurisdiction on the basis of an international agreement.

\section{(c) Summary}

It would seem that jurisdiction under Article 1 of the European Convention is basically territorial, although there are also areas of extraterritorial and quasi-territorial jurisdiction. The former does not call for further comment: maritime, aerial, spatial, diplomatic, consular, and other activities may generate attribution, State responsibility, and jurisdiction, as shown in ECTHR case law.

A question arises, however, when power is exercised across the border from outside a State's territory or from the air space or outer space. The Court's case law suggests that in such situations, there is extra-territorial (or quasi-territorial?) jurisdiction; this conclusion may be extplained by a desire on the part of the Court to offer as broad a protection of human rights as is possible. Indeed, in the absence of such jurisdiction, there might be no protection at all.

According to the Court's decision in Bankovic, quasi-territorial jurisdiction is not however generated by mere air raids because a certain degree of intrusiveness and duration is required. Moreover, the effect of the Convention was originally considered as being limited to the European region. But with the Iraqi cases, limitation tends to disappear. This means that the activities of armed forces deployed by European nations in any part of the world can now be ascribed to these nations.

Quasi-territorial jurisdiction was initially conceived for dealing with human rights infringements allegedly committed by occupants. It expanded constantly as a result of the presence of combined foreign troops after the second intervention in Iraq. As long as a specific operation complained of is conducted by a specific national contingent, responsibility seems to fall on and jurisdiction seems to extend to the national State of that contingent. This is true even if the orders are given by officers of the occupant or of the "leading nations". The policy of pushing quasi-territorial jurisdiction to such limits may invite criticism but is consistent with the Court's objective of providing full protection to the human rights of everyone.

Finally, responsibility and jurisdiction under Article 1 of the Convention are not generated by the mere fact that an individual complains of the conduct of an intergovernmental organisation established on its 
territory. They only are where the territorial State extends immunity to the organisation without having made sure that the organisation itself offers "equivalent" judicial protection.

\section{Results}

A general comparision of the four systems for the international protection of human rights examined in this contribution shows first that all of them embody some more or less compulsory elements. Recourse to the three regional mechanisms may result in conclusions binding on the defendant States. In some of them, implementation is entrusted to a judicial organ, in others to the executive arm of an international organisation. Regarding the ICCPR, the "sanction" will consist of publication and publicity only. This is hardly surprising since that system is potentially universal in character and therefore has a lower standard.

The African and American systems are two-tiered and partly modelled on the initial European mechanism: a commission with a court of justice above it. They differ by the fact that in the African mechanism, the Commission is freely accessible to individuals and NGOS, whereas the ACHPR is not open to individuals contrary to the IACTHR. In both systems, individual access to the courts depends on the respondent State's having declared its acceptance of jurisdiction. In the case of the ICCPR, individual communications may be entertained only if the respondent State is a Party to the Optional Protocol.

Viewed from this angle, the European mechanism is unquestionably the most sophisticated: individual applications can be levelled at any State Party to the ECHR; no declaration of acceptance is necessary. The Court is the only organ competent to deal with individual applications —although there are limited possibilities for having chambers' judgments re-examined by the Court's Grand Chamber.

Regarding jurisdiction ratione loci and ratione personae, all the instruments considered in the present contribution, except those relating to Africa, contain a provision on that issue. The reason for this exception remains a matter of conjecture. Is it because the authors of the African mechanism thought that no conflicts would arise? Is it in order to avoid following the European example? Or did the African States think that the rules of general international law on territorial and extraterritorial jurisdiction should apply in the event of conflicts? 
The ECHR and the ACHR both provide means for attributing responsibility to States Parties for conduct falling under their "jurisdiction" and, consequently, for the admissibility of applications when that condition is met. The ICCPR appears to be a case apart since Article 2.1 of its Protocol II seems to conbine the criteria of territoriality and jurisdiction.

Turning now to the practice examined in this contribution, the following conclusions may be drawn:

(i) There appears to be at least some practice of the ACHR showing that the organs of the ACHPR are not wholly unaware of the problem discussed here and that States Parties to the ACHPR may be held responsible for violations of the Charter committed outside their territory - a solution that conforms to the rules of general international law on the matter.

(ii) There also seem to be no precedents in the practice of the IACTHR. There was, however, a precedent in the framework of the IACHR concerning the conduct of us vessels on the high seas, outside American waters, which had forced Haitian refugee boats to return to where they had come from. This conduct was censored by the IACHR, with an approach that amounted to recognising a State's jurisdiction over the extraterritorial activities of its agents. That approach is likely to be emulated by the IACTHR if and when a relevant case arises.

(iii) As far as the ICCPR is concerned, practice is scant, but what there is of it seems to suggest the application of the general rules of international law as well. This suggestion is confirmed by General Comment No. 31, which indicates that the HRC will not apply the criteria of jurisdiction and territoriality cumulatively. This also results, indirectly but most importantly, from the advisory opinion of the ICJ in the $W$ all case.

(iv) Clearly, the most voluminous practice is that developed within the European system. Its main points can be summarised as follows: a) If a Convention State loses control over parts of its territory, it will not necessarily resort to Article 56 of the ECHR to limit its responsibility, because it may wish to avoid the impression that it has lost those parts (Assanidze); b) there are a number of classical situations where extraterritorial jurisdiction is exercised: on ships, aircraft, and space objects; through the activities of diplomats and consular agents; through action $a$ 
titre de sowverain on foreign territory by permission or toleration of the territorial State (see the Pirani case, for example); c) because it is a consequence of a foreign State's presence resulting from occupation or a similar situation.

Regarding the last-mentioned situations, it will be noted, especially on account of the Iraqi cases decided by the ECTHR, that the kind of control required for holding that a foreign State has jurisdiction has become increasingly loose. In earlier cases (Behrami and Sarwati), it had been held that if an international organisation retains ultimate control over a Chapter VII operation, there is no responsibility or jurisdiction of participating States, and control ultimately lies with the Security Council. Today a State involved in operations on foreign territory has to be neither an "occupant" in the classical sense of the term, nor a "leading nation" (Jaloud), nor need it exercise "overall control". Specific rather than overall control in a given situation will suffice.

A further element of looseness is the fact that when it is recognised that, despite the assertions of the ECTHR in its Bankovic decision, the ECHR is no longer regarded as a purely regional instrument. This is the result of the possibly understandable but perhaps misguided wish of the Court to provide as complete as possible a range of means for protecting human rights. If this trend persists, States may be less and less inclined to take part in Chapter VII operations to maintain peace and international security, for in every one of them there will be a risk of being accused of human-rights violations. Thus, while the world may be better protected against human rights violations, the primary goal of maintaining peace and international security would be increasingly endangered.

\section{References}

\section{Books}

Brownlie, I. \& Goodwin-Gill, G. (eds.) (2010). Brownlie's Documents on Human Rights, 6th ed. Oxford: Oxford University Press.

Buergenthal, T., (1981). "To Respect and to Ensure: State Obligations and Permissible Derogations”, in: L. Henkin (Ed.), The International Bill of Rights. The Covenant on Civil and Political Rights. New York: Columbia University Press, pp. $72-91$ (74). 
Caflisch, L. (2015). “The Iraqi Cases: Further Elements and Thoughts Concerning Jurisdiction under Article 1 of the European Convention on Human Rights", in Sošić, T., (Ed.), Liber Amicorum B. Vukas.

Fennell, S. \& Andoni, D., (Eds.) (2014), The African Court on Human and Peoples' Rights. Basic Documents. Oisterwijk, Netherlands: Wolf Legal Publishers, p. 75.

MacGregor, E. F. \& Pelayo Müller, C. M. (2014). "Artículo 1", in Steiner, C. \& Uribe, P. (Ed.), Convención Americana sobre Derechos Humanos. Comentario. Bogotá: Temis, pp. 42-68 (60).

Nowak, M. (2005). "UN Covenant on Civil and Political Rights". ICCPR Commentary, 2nd rev. ed., Kehl A. Rh., N. P. Engel, No. 27, p. 43.

Ouguergouz, F. (2014) The African Charter on Human and Peoples' Rights. The Hague: Nijhoff.

Parry, C. (ed.) (1907). Consolidated Treaty Series, Vol. 205.

Viljoen, F. (2008). "Communications under the African Charter: Procedure and Admissibility: The System in Practice, 1986-2006", in Evans, M. \& Murray, R., (Eds.). The African Charter on Human and Peoples' Rights. The System in Practice, 1986-2006, 2nd ed., Cambridge: Cambridge University Press, 76-138 (107).

\section{Journals}

"Pratique suisse en matière de droit international public 2013", No. 2.3, Revue suisse de droit international et européen, Vol. 25, 2015.

Bulto, T. S. (2011). "Patching the 'Legal Black Hole': The Extraterritorial Reach of States' Human Rights Duties in the African Human Rights System", South African Journal on Human Rights, Vol. 27, pp. 249-278 (258-260).

Caflisch, L. \& Kamga, M. (2015). "The Peaceful Settlement of International Disputes in Africa: Present and Future", African Yearbook of International Law, Vol. 20, pp. 361-408.

\section{Cases}

Assanidze v. Georgia, No. 71503/01, [GC], judgment of 8 April 2004.

Association pour la sauvegarde de la paix au Burundiv. Kenya, Rwanda, Tanzania, Zaire and Zambia, communication 157/96 (2003).

Bankovic and Others v. Belgium and Others, No. 52207/99, [GC], decision of 12 December 2001. 
Case No. 106/81, Montero v. Uruguay.

Case No. 52/79, López Burgos v. Uruguay; case No. 56/79, Lilian Celiberti de Casariego v. Uruguay.

Comité haitiano de Derechos Humanos et al., Report No. 51/96, case 10675.

Cyprus v. Turkey, No. 25781/94, [GC], judgment of 10 May 2001.

D. R. of Congo v. Burundi, Rwanda and Uganda, communication 227/99 (2003). Ilasscu and Others v. Moldova and Russia, No. 48787/99, [GC], judgment of 8 July 2004.

Legal Consequences of the Construction of a Wall in the Occupied Palestina Territories, advisory opinion of 9 july 2004, ICJ Reports 2004, p. 136.

Loizidou v. Turkey (preliminary objections), No. 15318/89, judgment of 23 March 1995. Cyprus v. Turkey, No. 25781/94, [GC], judgment of 10 May 2001.

Mohammed Abdullah Saleh Al-Asad v. Republic of Djibouti, communication 383/10 (2014).

No. 11987/11, decision of 28 January 2014.

No. 15521/08, decision of 6 January 2015.

No. 29750/09, [GC], judgment of 16 June 2014.

No. 42139/12, judgment of 21 April 2015.

No. 45036/98, [GC], decision of 30 June 2005.

No. 47708/08, [GC], judgment of 20 November 2014.

No. 55721/07, [GC], judgment of 7 July 2011.

Nos. 71412/01 and 71866/01, [GC], decision of 31 May 2007.

Pad and Others v. Turkey, No. 60167/00, decision of 28 June 2008.

Waite and Kennedy v. Germany, and Beer and Regan v. Germany, Nos 26083/94 and 28934/95, [GC], judgments of 18 February 1999.

\section{Documents}

29 March 2004, un Doc. ICCPR/C/21/Rev. 1/Add.13.

Article 4 of Protocol No. 15 of 24 June 2013, European Treaty Series No. 213.

Collected Edition of the Travaux préparatoires of the European Convention on Human Rights, Vol. III.

Convention Relative to the Treatment of Prisoners of War and Convention Relative to the Protection of Civilian Persons in Time of War.

Council of Europe. (2007). Human Rights in International Law, 3rd ed., Strasbourg: Council of Europe.

Document ICCPR/CO/78/ISR. 
European Treaty Series No. 5.

Fédération internationale des ligues des droits de l'homme (2010). Guide pratique: La Cour africaine des droits de l'bomme et despeuples.

Protocol of 16 December 1966, Council of Europe.

Report No. 86/99, Case 11589, 29 September 1999.

United Nations Treaty Series, Vol. 1155.

\section{Web pages}

www.achpr.org/instruments/rules-of-procedure-2010 
